\title{
The Influence of the Teacher's Civic Background and of the Teaching Quality on the Level of the Students' Civic Participation
}

\author{
Ph.D. Lindita Lutaj \\ University "Aleksandër Moisiu", Durrës; \\ Faculty of Education, Department of Pedagogy, Albania \\ Email: I.lutaj@yahoo.com
}

Doi:10.5901/jesr.2014.v4n4p296

\begin{abstract}
One of the main objectives of the Strategic Framework for European Collaboration in the field of education and training until 2020 is the promotion of the active civility via education. The scope of this study is reaching some objective conclusions with regard to the existent flaws and the students' civic background as well as the influence of this background on the active participation level for civic behaviour. It is also intended to study the connection between the civic and cultivated behaviour of the teachers, the teaching quality and the civic participation of the students. In this study, the measurement of the teachers' civic background and the teaching quality was carried out through the Likert scale. In order to measure the civic behaviours, questions with a scenario were applied, as the behaviours are better measured through the scenarios rather than the scales. The questionnaires were carried out in Durres and Elbasan among 414 students in the classes 6-9 and 34 teachers of the civility education. The statistical package of the social sciences (SPSS, 20) was applied for data analysis. In the civic background of the teachers, several factors resulted to be very essential. Some of these factors were: the civic engagement and values, where Chronbach's Alfa resulted to be 0,73. Meanwhile, in the teaching quality level other factors resulted to be crucial, such as: the quality of the class, the teaching methodology, the assessment methods, where Chronbach's Alfa resulted to be 0,67 .
\end{abstract}

Keywords: civic background, teaching quality, active participation, contribution.

\section{Summary}

The education of the right for civility has become recently the topic of the day in several countries, as a new century is approaching and an urgent consideration is given to the better preparation of the youngsters in order to cope with the challenges and the uncertainties of life, which is changing significantly (Ichilov, 1998). The Democratic Civic Education is an indicator of the education quality development of a country; it is a strong support for the social development and the adherence in the European Union (Gora etc., 2007, p.14). The basic concepts of the civic education in democracy and the curriculum material, which is focused on them, with the values it contains, are a good prospect for the development of the skills, resourcefulness and of the civic habits and manners. All these factors constitute an important element of the content of the general curricula and one of its main objectives to structure the active civic behaviour with the predisposition to participate in the social life (Tamo, 2002, p. 48). The reform in the field of the civic background intends to bring qualitative and stable changes to involve this change in its width and depth. The education for democratic civility should encourage and should be encouraged by a democratic learning environment in the school by interactive methods of participation and decision-making. The demand to change something in the teaching process of the subject of civic education is evident and becomes even more urgent because the status of this subject is becoming more special compared to the other subjects.

1.The status of the subject of civic education is conditioned by the mission the school has in the democratic society which intends to achieve the socialization and the humanization of the individual, his civic formation. 2 . It is conditioned by the current demands and the prospective the Albanian society has. The latter aspires for a consolidated democracy and for a rule of law (Sinani, 1997, p.4). The main purpose of education for the democratic civility is to develop, strengthen and protect the democratic culture of the rights and responsibilities, as the foundation of the voluntary effective and stable activity of the citizens. Therefore, it is closely connected to the recognition and the engagement towards the common democratic values and towards the institutions and the procedures which guarantee their further protection and development. Furthermore, it intends to offer continuous chances to win, enforce and spread the appropriate information, values, expressions and practices in all the formal and informal education environments; Birzea's reports, 1996, (Birzea, 1996) Veldhius, 1997 (Veldhius, 1997) and Audigier, 1999 (Audiger, 1999). In his study on the civic rights, Hahn (1998) found out that there are some significant changes among the countries with regard to the pedagogical traditions and 
cultural norms. He explains why the civility methods and programmes cannot be transported in a ready-made way from one country to another and to expect to be successful. The research indicates that the culture of the schools and of the classrooms is very low to adapt to the change (Fullan, 1991). The researchers have found that the civic recognition, the civic attitude and the civic skills are better acquired via the programs of the civic education, which adopts a more active methodology to instruct the participants (Whittley 2005). The active civility constitutes in itself a complexity of concepts, or fundamental values, which are common for all the modern democracies. The appropriate understanding of these concepts, values and of their relations in the conditions of rapid changes, as well as the dangers they contain, is the preliminary condition for an effective and responsible participation of the citizens in the process of democratic developments. If we want to have active civility, we have to face our rights and duties in the society, which originate from some rules and laws settled by our society, therefore we are asked to respect them. Civility is not something that happens itself. It can be developed only when a considerable number of people have the desire and the will to serve as decent citizens of the community. Civic education is crucial because every society needs people who can contribute effectively in different ways for a healthier community, for a better environment and for a stable development. The success of the education for an active and democratic civility depends significantly on the profession of teaching, where the teacher should support and encourage the students to become active citizens, as well as informed and responsible citizens to take responsibilities. "If you neglect the civic learning, it is the same as if you neglect an essential pillar of the American democracy. Our engagements for equality, the democratic accountability, the public discussion and a political culture based on the common values, all depend on the broad civic knowledge, the skills and the inclinations." (Report, Guardian of Democracy, 2003, p.15).

The year 2005 was declared by the Council of Europe as the European Year of Civility. Active civility is intended to be created through education, encouraging the development of initiatives and partnerships, as it needs the support of those individuals who cover the education for democratic civility, especially the support of the staff of the teachers, of the administrators of the schools and of the universities, of the compilers of the texts, of several operating organisations, etc.

The scope of this study is to reach objective conclusions with regard to the highlighting of the problems schools have, the deficiencies in education and the civic education of the students, the influence of this education on the level of active participation in civic actions. Above all special attention should be paid to the connection that exists between the civic background of the teachers, the teaching quality on one hand and the civic participation of the students on the other, to increase the quality of their work with regard to education and background for active civility of the future generations. It also intends to highlight the opportunities to improve the work in the future regarding the level of the students' active participation in the school and in the community.

"The key to be responsible in a modern society is to accept responsibilities for your own life; this is a virtue of the independence and autonomy. The independence of the judgement is as necessary as the independence of the action. The individual should be free to create the opinions himself". (Civic Education in Europe, 2000).

\section{Materials and Method}

This study analyzes the relation that exists between the quality of formation for civility in the school and the level of the students' civic participation. These indexes were measured in this study:

- $\quad$ The index of the teachers' civic background.

- The index of the teaching quality in the subject of civic education.

- The index of the students' civic participation.

Likert's scale was used for the measurement of the civic background and teaching, with five divisions (I totally agree (5), I agree (4), I am undecided (3), I do not agree (2) and I do not agree at all (1); as the scales are mainly used to measure the attitudes and the opinions. The questions with a scenario were used to measure the index of the civic behaviours, because the behaviours are better measured via the scenarios rather than the scales. The researchers who have used this method comment that in contrast to the common format of the questions involved in questionnaires, drafted in a foreign language of little interest, the cases under study are more effective measuring instruments to stimulate meaningful and believable answers (Seguin and Ambrosio, 2002; Barter \& Renold, 1999, 2002; Wason, Polonsky, \& Hyman, 2002; Neale, 1999). This happens because if they offer a similar context to the daily life of the answer-givers, they increase the probability that the answers might predict their real behaviour. During the exploration of the delicate topics, the answer to a hypothetical situation is less "threatening" than the direct questions for the experiences, beliefs or the personal attitudes (Lee), 1993 . Being administrated as supplements of the standard questions in the questionnaires, the cases under studies preserve the contextual validity of the instrument because the participants are asked to interpret and/or classify a situation or a concept in the study context (Martin, 2004). The concept of this 
study about the civic behaviours consists on several important indicators of civility, such as how much the students are informed about what is happening, how much they discuss with the others before they make a decision, the common decision-making, the action in collaboration with the others about several problems and the support of the community initiatives. 34 teachers, who teach Civic Education in the 6-9 classes, were included in this study; 9 of them in the district of Elbasan and 25 others in the district of Durres. The questionnaires were spread to 414 pupils; 299 pupils in the district of Durres and 115 pupils in the district of Elbasan.

\section{Results and Discussion}

34 teachers, who teach the subject of Civic Education in the 6-9 classes of the secondary education in the district of Durres and Elbasan, were involved in this study. None of them was graduated in the branch of Civic Education. They were graduated respectively: $17.6 \%$ history-geography-education; $26.5 \%$ history-geography; $8.8 \%$ history; $2.9 \%$ geography, 20.6\% language-literature; 5.9\% mathematics; 5.9\% biology-chemistry; 5.9\% elementary school teaching and $5.9 \%$ musical education. The graphic presentation is given below:

\section{Graduation of the Teachers Who Participated in the Study}

So in most of the cases, the subject of the civic education is taught by the teachers who are not in the profile. Sometimes, it is used as a subject to complete the teachers' teaching norm, thus not giving to it the status it deserves. "The teacher is competent for the subjects he/she teaches and for the teaching methods he/she uses." (IKT, 2008, Standardet e Përgjithshme bazë për mësuesin (General Basic Standards for the Teacher), p.8)

The statistical package of the social sciences was used for the analysis of the data (SPSS, 20). The descriptive data of the measuring scales is presented below:

Table 1: Descriptive data of the measuring scales

\begin{tabular}{lcccccccccc}
\hline & $\mathrm{N}$ & Average & Median & Mode & Stand. Dev. & Min & Max & Q1 & Q2 & Q3 \\
\hline Teachers' civic background & 414 & 33.4 & 34 & 36 & 4.2 & 16 & 40 & 31 & 34 & 37 \\
Teaching quality & 413 & 34.3 & 34 & 37 & 5.3 & 14 & 50 & 31 & 34 & 38 \\
\hline
\end{tabular}
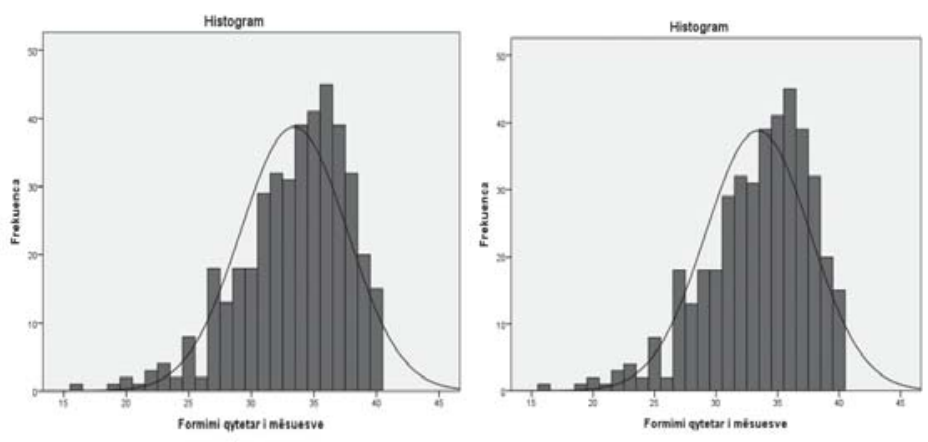

Graph 1: Values distribution according to the respective scales

\section{Analysis of the Scales Credibility}

The analysis of the scales credibility and of their factors was carried out after the factorial analysis.

- These codes were more dominant at the index of the teachers' civic background: the civic responsibilities and values, where Chronbach's Alfa was 0,73. Indexes such as collaboration, encouragement, stimulation, not being reserved and tolerance, resulted to be very crucial at the civic responsibilities. Meanwhile the transmission of the civic values from the teachers to the pupils and the establishment of the relations with the others had a crucial position among the civic values.

- The following indicators resulted to be crucial at the index of quality: class quality, students' learning, the use 
of the methods by the teacher during the class and the evaluation of the students, where Chronbach's Alfa resulted to be 0,67 . The results are presented in the following table:

Table 6: Presentation of the scales credibility and their factors

\begin{tabular}{clccc}
\hline Scale & \multicolumn{1}{c}{ Factor } & No. of confirmations & Chronbach's Alfa & N \\
\hline Civic background & & $\mathbf{8}$ & $\mathbf{0 . 7 3}$ & $\mathbf{4 1 4}$ \\
& Civic responsibilities & 5 & 0.67 & 414 \\
& Civic values & 3 & 0.54 & 414 \\
Teaching quality & & 10 & 0.67 & 414 \\
& Quality of the class & 4 & 0.57 & 414 \\
& Learning & 2 & 0.76 & 414 \\
& Evaluation method & 4 & 0.48 & 414 \\
\hline
\end{tabular}

\section{Conclusions and Recommendations}

This study intended to collect the teachers' and pupils' perceptions on the active civility. The results showed that it is time for a qualitative viewpoint of the civic education, in order to make it possible for people to participate actively in the solution of the problems. Common strategies are required for this issue to have successful practices, because our schools lack the qualitative steps regarding the education of the pupils to be active citizens of the future. This issue has been caused by the lack of collaboration among all the actors, the lack of the professionals graduated in the branch of civic education, the lack of civic education in the other branches, the lack of the trainings and of the experiences in this field, etc. However good a school might be, it cannot grow and develop qualitatively if it remains enclosed within its own walls. It should settle contacts with other schools, other education institutions, with the local authority, with other groups of interest, as well as with NGOs to improve the quality of the work in the future. The teacher's position is very essential. He should not get the ruling position, but he should create an environment where the pupils will feel well. In order for the teacher to be successful, he should use extra materials, should increase the request for the participation of the students in the class, should have organisational skills in and outside the classroom, should create a productive dialogue, should increase the interpersonal competences and collaborate with all the actors. The collaboration, the participation, the dialogue and the respect are words and attitudes which inspire the activities and the atmosphere of the life in the school. Civic education in school becomes possible via the creation of a positive atmosphere in the school, which stimulates self confidence, self appreciation and the reciprocal respect. As the role and the responsibilities increase, the teachers think about the ways that might contribute to improve the level of the students' active participation. The teachers should explore different working methods to increase the students' participation level in the school and in the community. The success does not depend only on the competences of the teachers themselves, but even on the students.

During this study, it was noticed that there is a relation between the teachers' civic background and the teaching quality on one hand, and the students' level of participation in the civic activities on the other one. Furthermore, this relation influences on the increase of the students' participation level in the civic activities. It was also noticed that the civic background of the teachers is more connected with the civic behaviours rather than the teaching quality. Females show higher levels of civic engagement, therefore they are more active than the boys. The pupils of the sixth classes report for more relations than the pupils of the other classes included in the study.

The teachers should continue their qualifications to improve their professional status in order to answer effectively to the students' need for civic engagements. Systematic programs of monitoring and consultancy at the school or regional level might be designed to assist the teachers to identify the students' difficulties as they face their responsibilities and performing their role in the school and in the community. The research shows that the students who attend courses of education for civility/civic education know more about the (formal and informal) political life, therefore they have more opportunities for participation in the future (Hahn, 1998; Niemi and Junn, 1998)

\section{References}

Audigier, F.Concepts de base et competences eles de leducation a la citoyennete democratique ; Une deuxieme synthese, Strasbourg ; Conseil de IEurope, 1999, document DECS/EUD/CIT(1999).

Birzea,C.Education for Democratic Citizenship-Consultation Meeting;General Report.Strasbourg; Councill of Europe, 1996, document DECS/CIT, (1996).

Barter, C. \& Renold, E. (1999). The use of vignettes in qualitative research. Social Research Update, 25, http://www.soc.surrey.ac.uk/sru 


\section{ISRU25.html}

Civic Education in Europe:Same General Principles. Universitat Boon, 2000.

Gora, C., Gore, V., Skolstvo, Z., (2007), Strategy for Civic Education in Primary and Secondary School in Montenegro 2007-2010, Unicef and the NGO Centre for Civic Education.

IKT, (2008), Standardet e Përgjithshme bazë për mësuesin, Tiranë.

Remaçka,L.,(2007), Revista Pedagogjike Nr.4, Universiteti i Torontos Kanada.

Report, (2003). Guardian of Democracy. The Civic Mission of Schools in partnership ëith the Educating for Democracy, University of Pennsylvania, Division for Public Education, National Conference on Citizenship.

Sinani,M., Myteberi, F.,(1997) Aspekte të mësimdhënies edukatë qytetare, Tiranë.

Seguin, C.A. \& Ambrosio, A.L. (2002). Multicultural vignettes for teacher preparation. Multicultural Perspectives, 4, 10-16.

Shakaj,I., (2012). Didaktika e edukimit për qytetari demokratike, Julvin 2, Tiranë.

Tamo, A., Rapti, E., Karaj, Th., (2005) Mësimdhënia dhe të nxënit, Mokra, Tiranë .

Tamo,A., (2002). Edukimi qytetar në shkollë e jashtë saj, Qëndra e zhvillimit human, Tiranë.

Veldhuis, R.Education For Democratic Citizenship; Dimensions of Citizenship, Core Competencies. Variables and International Activities, Strasbourg; Council of Europe, 1997, document DECS/CIT(1997) .

Wason, K.D., Polonsky, M.J., \& Hyman, M.R. (2002). Designing vignette studies in marketing. Australasian Marketing Journal, 10, 41-58. 